\title{
Współczesne obszary występowania mołdawitów - wnioski z eksperymentu transportowania ich przez Nysę Łużycką
}

\author{
Tomasz Brachaniec ${ }^{1}$
}

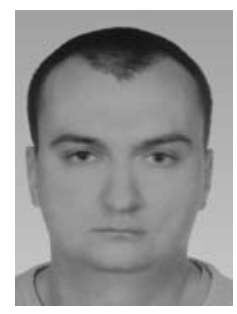

Modern areas of occurrence of moldavites - conclusions from their experimental transport across the Lusatian Neisse. Prz. Geol., 70: 61-65; doi: 10.7306/2022.4

A b s tra c t. Tektites in the sedimentary record are subject to many geological processes such as fluvial reworking. To observe the glass behaviour during reworking, an experiment was conducted in the Lusatia Neisse river where moldavites are found. It consisted in observing the progressive abrasion of some 500 tektites over reworking distances of 100,200, 300, and $400 \mathrm{~km}$ respectively. The results clearly show that moldavites could survive reworking over a distance of several hundreds $\mathrm{km}$. The decrease in weight was linear in relation to the distance travelled. Regardless of the initial shape, all tektites became rounded with a smooth surface after travelling $200 \mathrm{~km}$. The experimental results suggest that European tektites were ejected from the Ries crater over distances reaching up to $600 \mathrm{~km}$ and were then reworked over short distances from the origin areas of the current substrewn fields.

Keywords: tektite, moldavite, reworking, abrasion, redeposition, strewn field

Spadek ciała kosmicznego w osady bogate w krzemionkę prowadzi do ich przetopienia. Okruchy szkliwa powstałe po zastygnięciu takiego płynnego stopu są nazywane tektytami. Kenozoiczne tektyty składają się z bezpostaciowego szkliwa (Lyttleton, 1968). Szkliwo starszych tektytów uległo przekształceniu w minerały ilaste (Brachaniec in., 2014a). Europejskie tektyty, zwane mołdawitami, są wiązane z impaktem Ries, datowanym na 14,93-15 Ma (Rocholl i in., 2017), czyli środkowy miocen (baden). Występują one na terenie Polski - m.in. w osadach Nysy Łużyckiej - Niemiec, Czech oraz Austrii (np. Paszcza,
2021). Wszystkie obszary występowania mołdawitów w środkowej Europie (ryc. 1A) podlegały procesom fluwialnym, w wyniku których szkliwa ulegały systematycznej abrazji, redystrybucji i redepozycji. Zarówno wyniki prac laboratoryjnych (Hurtig, 2019), jak i wstępne obserwacje terenowe (Brachaniec, 2020a) wskazują, że odporność tektytów na obróbkę wodną jest większa, niż wcześniej zakładano (Žebera, 1972; Bouška i in., 1999; Trnka, Houzar, 2002; Brachaniec, 2018a, b, 2019a, b) i mogą one przetrwać transport rzeczny na dystansie kilkuset kilometrów. W celu udokumentowania przebiegu procesu

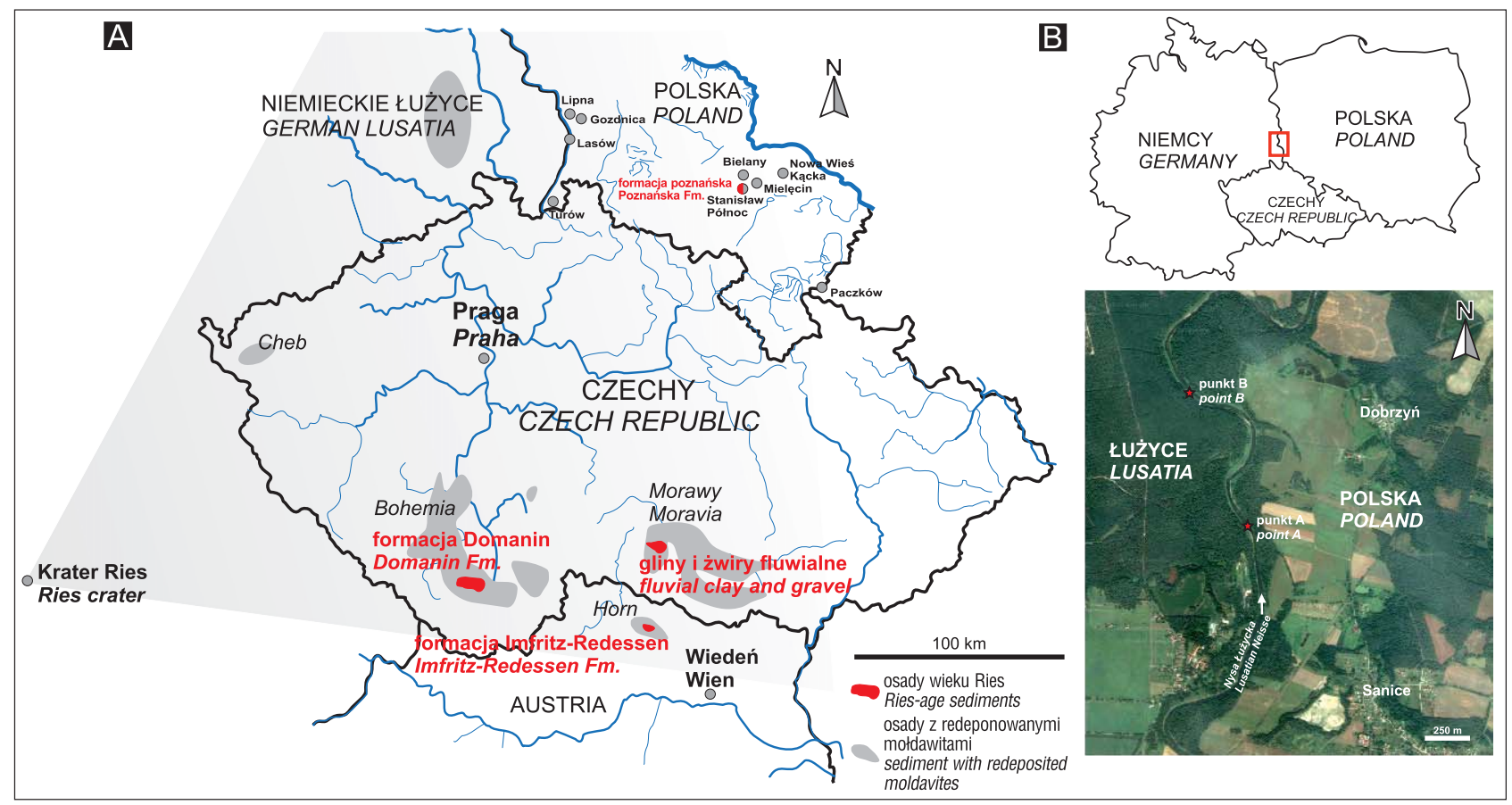

Ryc. 1. A - Obszary występowania mołdawitów na terenie środkowej Europy (wg danych z 13.07.2021 r.). B - Lokalizacja obszaru badań na wybranym odcinku Nysy Łużyckiej, na którym obserwowano abrazję mołdawitów podczas kontrolowanego transportu rzecznego

Fig. 1. A - Areas of occurrence of moldavites in central Europe (as of 13.07.2021). B - Location of the study area located on a selected section of the Lusatian Neisse River, where abrasion of the Moldavian was observed during controlled river transport

\footnotetext{
${ }^{1}$ Wydział Nauk Przyrodniczych, Uniwersytet Śląski, ul. Będzińska 60, 41-200 Sosnowiec; tomasz.brachaniec@o2.pl
} 
abrazji mołdawitów, a także oszacowania na tej podstawie możliwego zasięgu ich występowania na terenie środkowej Europy, przeprowadzono eksperyment polegający na poddaniu wybranych ziaren mołdawitów kontrolowanemu transportowi rzecznemu i obserwacji postępu ich abrazji.

\section{OBSZAR BADAŃ}

Badania przeprowadzono na Nysie Łużyckiej, która stanowi naturalną granicę polsko-niemiecką. Do obserwacji wybrano odcinek rzeki o długości $1 \mathrm{~km}$, na stosunkowo płaskim terenie pomiędzy miejscowościami Sanice i Dobrzyń (ryc. 1B). Bieg rzeki na tym odcinku w górnej części jest prosty na długości $250 \mathrm{~m}$, następnie ma dwa zakola o łącznej długości $650 \mathrm{~m}$ i na koniec przechodzi w 100-metrowy odcinek prosty. Średnia głębokość Nysy Łużyckiej wynosi na wybranym odcinku $1 \mathrm{~m}$, natomiast jej koryto ma szerokość $6 \mathrm{~m}$, lecz miejscami zwęża się ono do 3-4 m. Prędkość przepływu wód w trakcie badań oszacowano na $2,5 \mathrm{~km} / \mathrm{h}$. W ważącej $10 \mathrm{~kg}$ próbie osadów pobranych z dna rzeki $60 \%$ (6 kg) stanowił piasek średnioziarnisty, a pozostałe $40 \%$ (4 kg) żwir składający się głównie z klastów kwarcytów i gnejsów o średnicy 5-10 cm.

\section{METODYKA}

Wszystkie mołdawity, niezależnie od obszaru występowania, mają identyczne cechy fizyczne i chemiczne (Rodovská i in., 2016). W związku z tym do przeprowadzenia eksperymentu użyto 500 czeskich mołdawitów, które są łatwo dostępne. Mołdawity te ważyły 1,112-5,946 g, były ciemnozielone, miały podłużny kształt, długość 15-64 mm i głęboko ornamentowaną powierzchnię. Tektyty wybierano do eksperymentu losowo, toteż ich zbiór nie miał rozkładu normalnego (ryc. $3 \mathrm{~A}$ ).

Mołdawity wrzucano do Nysy Łużyckiej w punkcie A (ryc. 1B) po czym, gdy pokonały one dystans $1 \mathrm{~km}$, przechwytywano je na sito o średnicy oczek $5 \mathrm{~mm}$ w punkcie B - długość zakoli rzeki obliczono na podstawie wzoru długości łuku $\left(\alpha / 360^{\circ}\right) 2 \pi$ r. Punkt B wybrano w miejscu, gdzie koryto rzeki zwęża się do ok. 3 m, co ułatwiło stabilizację sita w dnie rzeki na całej jej szerokości. Po wyłowieniu mołdawitów poddawano je obserwacjom makroskopowym, oceniając zmiany powstałe w strukturze szkliwa, mierzono je i ważono, a także odświeżano ich numerację za pomocą wodoodpornego cienkopisu. Następnie zanoszono je do punktu A i ponownie wrzucano do wody.

Pierwotnie przyjęto, że transport mołdawitów będzie się odbywać w kolumnie wody Nysy Łużyckiej. Chcąc ocenić tempo tego transportu, zmierzono prędkość przepływu rzeki z zastosowaniem pływaków (pomiar prędkości przepływu wody polegał na pomiarze czasu, w którym pływak przebył odcinek o długości $100 \mathrm{~m}$ ). W ten sposób teoretycznie (błędnie) wyliczono, że transport mołdawitów na dystansie $1 \mathrm{~km}$ (czyli jeden cykl badań) będzie trwać ok. 24 minut. Mołdawity nie były jednak transportowane w kolumnie wody, lecz w strefie przydennej, w której podlegały tarciu, a także w bocznych strefach koryta, gdzie energia przepływu była znacznie mniejsza. $\mathrm{W}$ związku $\mathrm{z}$ tym ich transport trwał znacznie dłużej. Aby skrócić czas całego eksperymentu, pojedynczy cykl kończono po 45 minutach - bez względu na to, ile tektytów zarejestrowano na sicie. Toteż po każdym cyklu wyłapywano ich coraz mniej. Tektyty, które nie zostały złapane na sito w ciągu 45 minut, mogły przybyć do punktu B w późniejszym czasie, jednak nie były już uwzględniane w wynikach badań. Eksperyment zakończono po 400 cyklach, czyli gdy tektyty przebyły dystans $400 \mathrm{~km}$.

Postęp abrazji mołdawitów podsumowano w czterech głównych etapach eksperymentu, tj. po 100, 200, 300 oraz 400 cyklach transportu. W opisie kształtów szkliwa przyjęto klasyfikację Powersa (1953).

\section{WYNIKI}

Pierwszy etap - $100 \mathrm{~km}$ transportu rzecznego. Po przebyciu 100 kilometrów transportu rzecznego zauważalnie zmniejszył się stopień nieregularności form badanych ziaren mołdawitów - na skutek abrazji ziarna ostrokrawędziste przekształciły się w ziarna półobtoczone (ryc. 2).

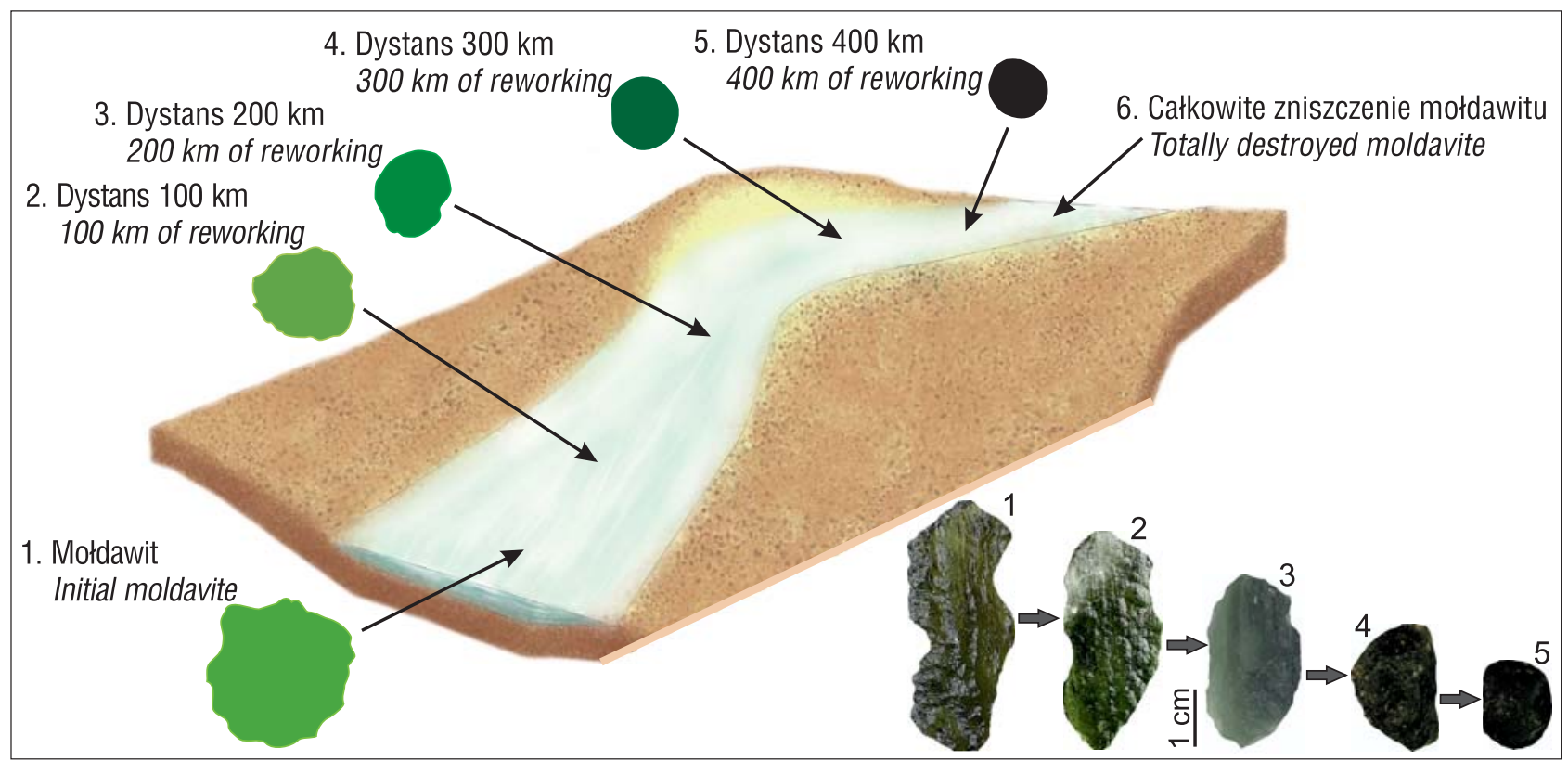

Ryc. 2. Etapy abrazji mołdawitów podczas transportu rzecznego

Fig. 2. Stages of abrasion of moldavians during river transport 
Powierzchnia tektytów stała się bardziej matowa i mniej przezroczysta. Pierwotna ornamentacja nadal była widoczna, ale została częściowo wygładzona. Masa poszczególnych mołdawitów zmniejszyła się o 0,3 do 89,6\%. Średni ubytek wagi wyniósł 18,6\% (ryc. 3B i 4).

Drugi etap - $200 \mathrm{~km}$ transportu rzecznego. Wszystkie tektyty, które pokonały w wodzie dystans 200 km, były zaokrąglone, a ich powierzchnia stała się matowa i nieprzezroczysta (ryc. 2). Pierwotna ornamentacja została zatarta.
Między 100 a $200 \mathrm{~km}$ transportu mołdawity straciły 34,7\% swojej masy (ryc. 3C i 4).

Trzeci etap - $300 \mathbf{~ k m}$ transportu rzecznego. Na tym etapie wszystkie ziarna szkliwa były bardzo dobrze zaokraglone i miały matową, wygładzoną, nieprzezroczystą i prawie czarną powierzchnię (ryc. 2). Mołdawity poddane eksperymentowi, przemieszczając się po dnie rzeki z punku A do punktu B, na odcinku od 200 do $300 \mathrm{~km}$ straciły średnio 59,1\% swojej masy (ryc. 3D i 4).

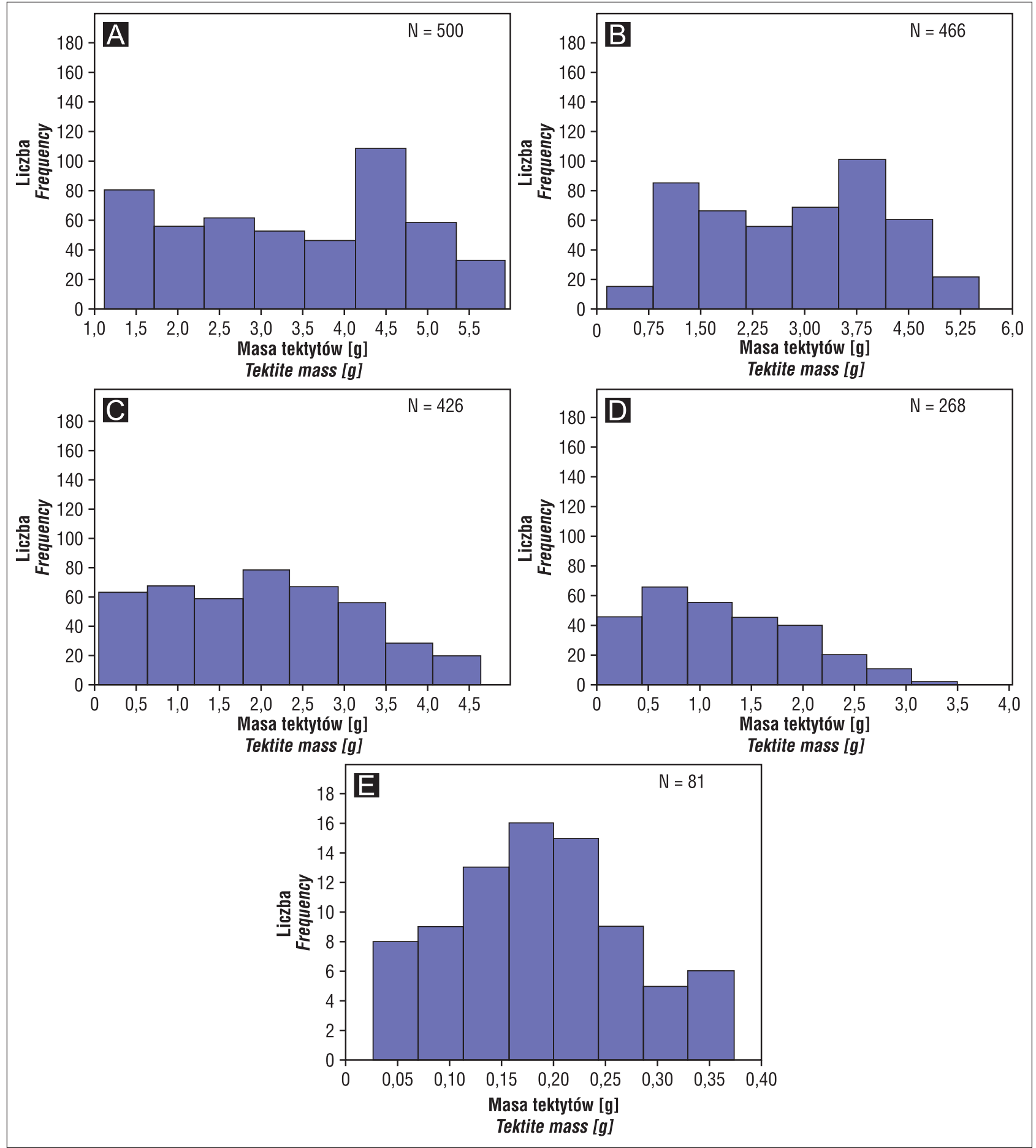

Ryc. 3. Masa mołdawitów na poszczególnych etapach transportu fluwialnego: A-początek trasy, B - po $100 \mathrm{~km}$ transportu, C - po 200 $\mathrm{km}$ transportu, D - po $300 \mathrm{~km}$ transportu, $\mathbf{E}$ - po $400 \mathrm{~km}$ transportu; $\mathbf{N}$ - liczba tektytów

Fig. 3. Distribution of mass of moldavians at successive stages: $\mathbf{A}$ - starting point, $\mathbf{B}-100 \mathrm{~km}$ distance, $\mathbf{C}-200 \mathrm{~km}$ distance, $\mathbf{D}-300 \mathrm{~km}$ distance, and $\mathbf{E}-400 \mathrm{~km}$ distance: $\mathbf{N}$ - number of tektites 


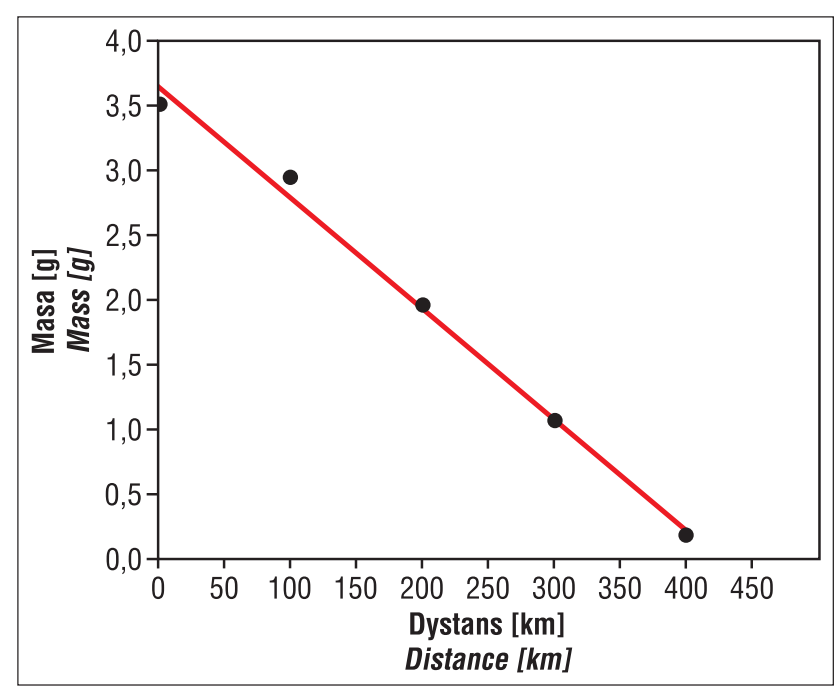

Ryc. 4. Zależność spadku średniej masy tektytów od przebytego dystansu transportu rzecznego

Fig. 4. Dependence of the decrease in mean tektite mass on the distance travelled in river transport

Czwarty etap - $400 \mathrm{~km}$ transportu rzecznego. Forma i powierzchnia ziaren mołdawitów, które przetrwały $400 \mathrm{~km}$ transportu rzecznego, prawie nie różniły się od obserwowanych na poprzednim etapie (ryc. 2). Jednak na tym ostatnim 100-kilometrowym dystansie nastapił znaczący spadek ich masy - średnio aż o 90,6\% (ryc. 3E i 4).

Po 100 cyklach transportowania mołdawitów przez wody Nysy Łużyckiej na odcinku o długości $1 \mathrm{~km}$ na sicie odłowiono 466 mołdawitów, po 200 cyklach - 426, po 300 -268, a po 400 tylko 81 , czyli $16,2 \%$ z początkowych 500 ziaren przeznaczonych do badań. Diagramy obrazujące liczbę mołdawitów wyłapanych na sicie na poszczególnych etapach eksperymentu i ich masę wyraźnie wskazują, że dane te prezentują statystyczny rozkład normalny (ryc. 3B-E). Można zatem wysnuć wniosek, że postępująca abrazja najintensywniej działa na tektyty o masie zbliżonej do skrajnych wartości przedziału. Wykres zależności utraty masy przez mołdawity od dystansu transportu odbytego w rzece ma przebieg liniowy (ryc. 4).

\section{DYSKUSJA}

Znalezienie mołdawitów na terenie południowo-zachodniej Polski (Brachaniec i in., 2014b, 2015, 2016; Brachaniec, 2017; Szopa i in., 2017, 2019), w odległości ok. $500 \mathrm{~km}$ od macierzystego krateru Ries (ryc. 1A), rzuciło nowe światło na zasięg występowania tych tektytów na terenie Europy. Tylko cztery formacje skalne, które zawierają mołdawity, są równowiekowe z impaktem Ries. Są to: formacja Domanin w południowych Czechach, fluwialne piaski ze żwirem na zachodnich Morawach, austriacka formacja Imfritz-Radessen oraz formacja poznańska w południowo-zachodniej Polsce (Trnka, Houzar, 2002; Sevčík i in., 2007; Brachaniec, 2020b). Depozycja tektytów w tych utworach musiała nastąpić bardzo szybko świadczą o tym urozmaicona morfologia ziaren mołdawitów oraz wiek osadów, w których są znajdowane. Wszystkie inne wystąpienia mołdawitów opisano $\mathrm{z}$ utworów późnego miocenu i plejstocenu, co świadczy o ich redepozycji. Również mołdawity napotykane w młodszych osadach są ostrokrawędziste, najczęściej o głębokiej i złożonej ornamentacji powierzchni. Wszystkie znane obszary wystąpień redeponowanych mołdawitów prawie pokrywają się z obszarami, na których w osadach równowiekowych z impaktem Ries są obecne szkliwa nieredeponowane (ryc. 1A). W tej sytuacji możliwy jest tylko jeden scenariusz - w czasie co najmniej kilku milionów lat mołdawity były transportowane na niewielką odległość (do $100 \mathrm{~km}$ ). Można zakładać, że były częściowo wymywane z osadów środkowego miocenu i deponowane w młodszych osadach, jednak na tym samym obszarze geograficznym. Nasuwa się więc pytanie, w jaki sposób mołdawity trafiły do tak odległych obszarów od krateru Riess, jak czeski Cheb i niemieckie Łużyce?

W świetle wyników eksperymentu opisanego w niniejszym artykukle niemożliwe jest, by ziarno mołdawitu po kilkusetkilometrowym transportcie wodnym zachowało zarówno swój pierwotny kształt, jak i ornamentację. Wydaje się zatem, że w badenie istniało wiele formacji osadowych z mołdawitami, które były systematycznie wymywane aż do całkowitego zerodowania. Istnienie badeńskich osadów mołdawitonośnych oddalonych nawet o $600 \mathrm{~km}$ od krateru Ries zostało potwierdzone na drodze symulacji komputerowych (Stöffler i in., 2002; Artemieva i in., 2013), natomiast Skála i in. (2016) sugerują, że w Europie mogą istnieć nieznane jeszcze obszary występowania mołdawitów.

\section{PODSUMOWANIE I WNIOSKI}

Wyniki eksperymentu przeprowadzonego na Nysie Łużyckiej potwierdziły wnioski Hurtiga (2019) oraz Brachańca (2020a) o dużej odporności tektytów na abrazję fluwialną. Podczas pierwszych $100 \mathrm{~km}$ transportu rzecznego mołdawity częściowo tracą swój pierwotny kształt, ornamentację i transparentność. Po $200 \mathrm{~km}$ ich ziarna stają się wyraźnie zaokraglone, o prawie gładkiej i matowej powierzchni. Po przebyciu $300 \mathrm{~km}$ postępująca abrazja sprawia, że przyjmują one kształty kuliste, a ich kolor staje się znacznie ciemniejszy od obserwowanego po krótszych dystansach transportu. Przebycie trasy o długości $400 \mathrm{~km}$ sprawia, że ziarna mołdawitów stają się kuliste i bardzo ciemne, prawie czarne. Wraz z wydłużaniem się drogi transportu ziaren mołdawitów zwiększało się średnie tempo utraty ich masy. Na odcinku 0-100 m tektyty średnio utraciły $18,6 \%$ swojej masy, na dystansie $100-200 \mathrm{~m}-34,7 \%, 200-300 \mathrm{~m}-59,1 \%$, a na ostatnim etapie aż 90,6\%. Utrata masy tektytów, jaka nastąpiła podczas ich transportowania przez Nysę Łużycka, jest bardzo zbliżona do otrzymanej w eksperymencie przeprowadzonym na Łabie (Hurtig, 2019), w osadach której również są znajdowane mołdawity.

Dystans, jaki mołdawity mogą pokonać w toni wodnej, determinuje ich początkowa masa, energia środowiska oraz rodzaj osadu na dnie koryta rzeki. Tektyt o masie kilku gramów pokona znacznie większy dystans w wolno płynącej rzece o dnie piaszczystym, niż mniejszy tektyt toczony z dużą siłą po dnie żwirowym. Transport mołdawitów sieciami mioceńskich rzek niewątpliwie był możliwy na dystansie do kilkuset kilometrów. Odległość, jaką ziarno tektytu mogło przetrwać w tych warunkach, zależała głównie od jego masy początkowej. Większość współczesnych wystapień mołdawitów jest efektem wymywania ich z osadów środkowomioceńskich, a następnie redepozycji w młodszych osadach, jednak znajdujących się w niewielkiej odległości (ok. 100 km) od osadów macierzystych. 
Zmienność energii środowiska, rodzaju i ilości osadu na dnie rzeki, a także morfologii koryta powoduje, że podobne eksperymenty wykonywane w stałych warunkach laboratoryjnych nie dają rzeczywistych wyników (Brachaniec, 2018a).

Dziękuję dr hab. Julicie Biernackiej i dr. Pawłowi Raczyńskiemu za recenzję artykułu i konstruktywną krytykę. Specjalne podziękowania składam także kolegom: Kamilowi Rudzkiemu, Danielowi Tarnikowi oraz Łukaszowi Kowalowi za udział w pracach terenowych.

\section{LITERATURA}

ARTEMIEVA N.A., WÜNNEMANN K., KRIEN F., REIMOLDW.U., STÖFFLER D. 2013 - Ries crater and suevite revisited - Observations and modeling. Part II: Modeling. Meteoritics \& Planetary Sci., 48 590-627.

BOUŠKA V., KADLEC J., ŽAK K. 1999 - Moldavite aus demwestlichen und demnordlichen Teil Bohmen. Staatliches Museum für Mineralogie und Geologie, Dresden, 10: 16-19.

BRACHANIEC T. 2017 - The most distal moldavite findings from Lower Silesia, Poland. Carnets de Géologie, 17: 139-144.

BRACHANIEC T. 2018a - An experimental model for the tektite fluvia transport based on the most distal Polish moldavite occurrences. Meteoritics \& Planetary Sci., 53: 505-513.

BRACHANIEC T. 2018b - Variations in fluvial reworking of Polish moldavites induced by hydrogeological change. Carnets de Geologie, 18: 225-232.

BRACHANIEC T 2019a - Relationship between the abrasion of tektite clasts and their host sedimentary facies, Pleistocene, SW Poland. Ann. Soc. Geol. Polon., 89: 83-90

BRACHANIEC T. 2019b - Susceptibility of various tektite types to fluvial abrasion. Geol. Quart., 63: 150-161.

BRACHANIEC T. 2020a - A scheme for moldavite fluvial abrasion based on observations from natural river stream. Meteoritics \& Planetary Sci., 55: 2171-2183.

BRACHANIEC T. 2020b - Moldavite finds in Middle Miocene (Langhian Stage) deposits of southwestern Poland. Carnets de Geologie, 20: 241-247.

BRACHANIEC T., KARWOWSKI Ł., SZOPA K. 2014a - Spherules associated with the Cretaceous-Paleogene boundary in Poland. Acta Geol. Polon., 64: 99-108.

BRACHANIEC T., SZOPA K., KARWOWSKI Ł. 2014b - Discovery of the most distal Ries tektites found in Lower Silesia, southwestern Poland. Meteoritics \& Planetary Sci., 49: 1315-1322.
BRACHANIEC T., SZOPA K., KARWOWSKI Ł. 2015 - A new discovery of parautochthonous moldavites in southwestern Poland, Central Europe. Meteoritics \& Planetary Sci., 50: 1697-1702.

BRACHANIEC T., SZOPA K., KARWOWSKI Ł. 2016 - New moldavites from SW Poland. Acta Geol. Polon., 66: 99-105.

HURTIG M. 2019 - Experimental study of abrasion of tektitesand other glasses in the course of fluvial transport over long distances (abstract \#1169). $50^{\text {th }}$ Lunar and Planetary Science Conference. CD-ROM.

LYTTLETON R. A. 1968 - On the origin of tektites. Geophysical Journal of the Royal Astronomical Society, 15: 191-204.

PASZCZA K. 2021 - Nowe znaleziska polskich tektytów z obszaru niecki żytawskiej. Prz. Geol., 69: 244-247.

POWERS M.C. 1953 - A new roundness scale for sedimentary particles. J. Sedim. Petrol., 23: 117-119.

ROCHOLL A., SCHALTEGGER U., GILG H.A., WIJBRANS J., BÖHME M. 2017 - The age of volcanic tuffs from the Upper Freshwater Molasse (North Alpine Foreland Basin) and their possible use for tephrostratigraphic correlations across Europe for the Middle Miocene. Intern. J. Earth Sci., 107: 387-407.

RODOVSKÁ Z., MAGNA T., ŽÁK K., SKÁLA R., BRACHANIEC T., VISSCHER C. 2016 - The fate of moderately volatile elements in impact events-Lithium connection between the Ries sediments and central European tektites. Meteoritics \& Planetary Sci., 51: 2403-2415.

ŠEVČÍK J., KVAČEK Z., MAI D.H. 2007 - A new mastixioid florula from tektite-bearing deposits in South Bohemia, Czech Republic (Middle Miocene, Vrábče Member). Bull. Geosci. 82: 429-426.

SKÁLA R., JONÁŠOVÁ S., ŽÁK K., ĎURIŠOVÁ J., BRACHANIEC T., MAGNA T. 2016 - New constraints on the Polish moldavite finds: a separate sub-strewn field of the central European tektite field or re-deposited materials?. J. Geosci., 61: 171-191.

STÖFFLER D., ARTEMIEVAN.A.,PIERAZZO E. 2002 - Modeling the Ries-Steinheim impact event and the formation of the moldavite strewn field. Meteoritics \& Planetary Sci., 37: 1893-1907.

SZOPA K., BADURA J., BRACHANIEC T., CHEW D., KARWOWSKI Ł. 2017- Origin of parautochthonous Polish moldavites - a palaeogeographical and petrographical study. Ann. Soc. Geol. Polon., 87: 1-12.

SZOPA K., BRACHANIEC T., KARWOWSKI Ł. 2019 - Polskie mołdawity: obecny stan wiedzy i perspektywy nowych znalezisk. Prz. Geol., 67: 662-667.

TRNKA M., HOUZAR S. 2002 - Moldavites: a review. Bull. Czech Geol. Survey, 77: 283-302.

ŽEBERA K. 1972 - Vltaviny v katastrofalnych pøivalovych sedimentech u Prahy. Geologicky Prùzkum, 14: 54-56.

Praca wpłynęa do redakcji 14.07.2021 r.

Akceptowano do druku 29.11.2021 r. 